Tér és Társadalom 14. évf. 2000/2-3. 43-52. p.

Tér és Társadalom

XIV. évf. 2000 2-3: 43-52

\title{
IPARI KLASZTEREK
}

\author{
(Industrial Clusters)
}

\section{GROSZ ANDRÁS}

Az ipari klaszterek ${ }^{1}$ a regionális gazdaságfejlesztés egyik legdivatosabb eszközévé váltak az elmúlt néhány évben (Dỏry 1999; Lengyel 1999; Porter 1999; Rechnitzer 1998; Roelandt-den Hertog 1998; Steiner 1998). Európa legfejlettebb gazđasággal renđelkező országaiban - csakúgy, mint a tengerentúlon -a regionális léptékủ gazdaságok életében mind fontosabbá válnak a koncentrált együttmúköđési hálózatok, aminek köszönhetően ma már világszerte több száz klasztert tartanak nyílván. Csak néhányat megemlítve a legismertebbek közül: a Detroit környéki autógyártás, a számítástechnika és az információs technológia koncentrációja a Szilícium-völgyben, az úgynevezett Harmadik Itália kis- és középvállalkozásai, a svájci óragyártás, vagy a pénzügyi szektor kiemelkedő szerepe New Yorkban és Londonban. Sikerük hatására az elmúlt időszakban hazánkban is egyre többet hallani különbözö ipari klaszterek létrehozásáról és annak kormányzati támogatásáról (Döry 1999). Ennek fényében szeretnénk áttekinteni, és röviden felvázolni az ipari klaszterek elméleti hátterének néhány szeletét.

\section{Regionális versenyképesség}

A klaszterek megértéséhez elengedhetetlen a regionális versenyképesség megértése. A regionális versenyképesség terén az első mérföldkövet Marshallnak az ipari körzetekkel foglalkozó munkája jelentette, amely elöször világít rá a gazdaság földrajzi koncentrációja által elöidézett pozitív agglomerációs hatások jelentőségére (Marshall 1890). Míg a hetvenes években a regionális termelékenységben tapasztalható különbségeket a termelési funkciók oldaláról közelítették meg, addig a nyolcvanas években a földrajzilag koncentrált vállalkozások közötti együttmüködésekben rejlö elönyökre helyeződött a hangsúly. A kilencvenes években pedig Porter a versenyképesség oldaláról megközelítve fedezte fel újra a klaszterek jelentőségét, lehetöséget teremtve számos új kutatásnak e téren. A Porter-féle Gyémánt-modell (1. ábra) négy alapvető determinánsból épül fel, melyek azonban nem elszigeteltek, hanem kölcsönös függésben állnak, és egymást erösítik. Egy régió azon iparágban képes a legsikeresebb lenni, amelyben valamennyi tényezỏ és a köztük lévő kölcsönhatás egyszerre mutat kedvezö képet (Lengyel 1999; Porter 1990).

- Tényezóellátottság (a termelési tényezők feltételei): a rendelkezésre álló humánerőforrások illetve természeti erőforrások, a meglévő tudásbázis, a felhasználható pénzügyi források valamint a szuikséges infrastruktúra. 
- Keresleti feltételek: a hazai kereslet összetétele mellett különös jelentőséggel bír a kifinomult ízlésü igényes vásárlók által támasztott kereslet, valamint megkerülhetetlen a kereslet nemzetközivé tétele.

- Támogató és kapcsolódó iparágak: az iparágat inputokkal ellátó többi támogató és kapcsolódó iparág.

- Vállalati stratégia, szerkezet és rivalizálás: döntő szerepe van a térség vállalatai versenystratégiájának, az általuk kitüzött új célok megjelenésének, illetve a belföldi versengésnek.

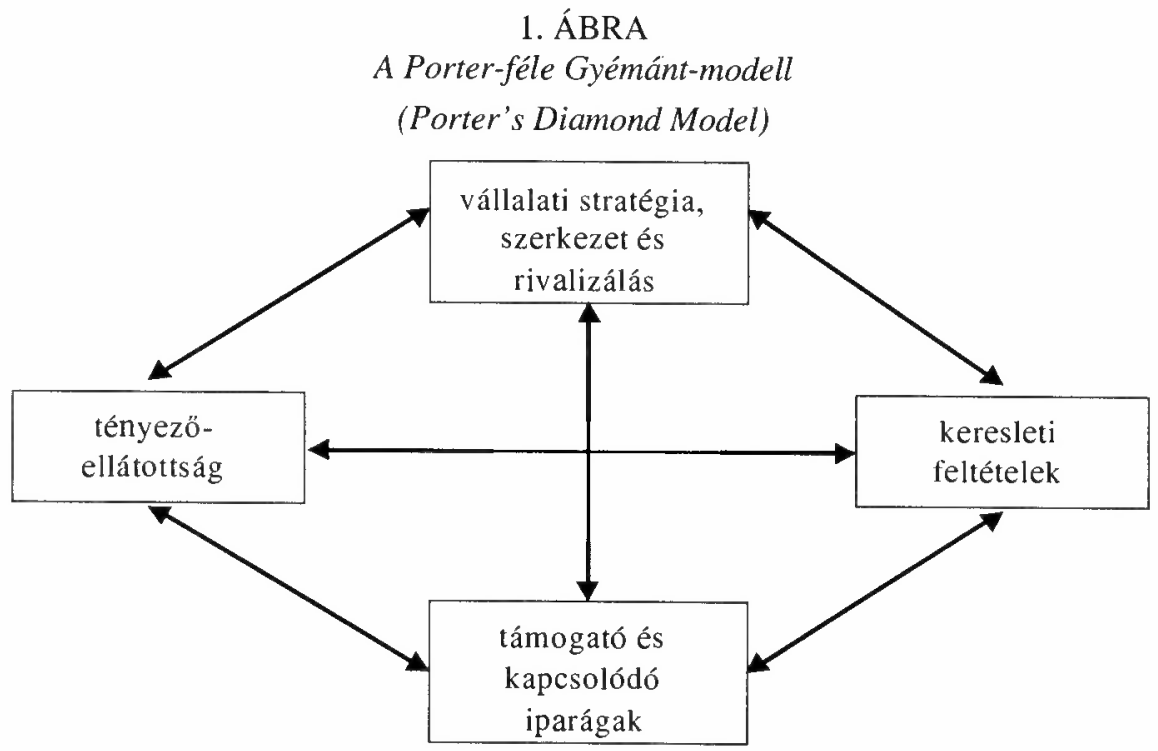

Forrás: Porter 1990.

\section{Mi is az a klaszter?}

A szakirodalomban a klaszter fogalmával kapcsolatban egyetlen dologban mutatkozik egyetértés, mégpedig abban, hogy a klaszter fogalmát illetöen nincs egyetértés, az a vizsgálat dimenziójától és a megközelítés módjától függöen változhat (Döry 1998; 1999; Faragó 1994; Porter 1999; Roelandt-den Hertog 1998; Steiner 1998). Porter szerint a klaszter nem más, mint „... egy bizonyos müködési területen belül tevékenykedő, egymással kapcsolatban álló vállalatok és intézmények földrajzi tömörülései, amelyekben jelen van a versenyszempontból fontos iparágak széles skálája" (Porter 1999, 7.). Különösen fontos, hogy a klaszter résztvevői szervezetileg egymástól függetlenek, és sajátos vásárlói, beszállítói, $\mathrm{K}+\mathrm{F}$ stb. kapcsolatban állnak egymással (Faragó 1994). Roelandt és den Hertog a termelési hálózatoknak a közös értéklánc mentén történő kapcsolódását emeli ki (Roelandt-den Hertog 1998). 
Tehát a továbbiakban egy olyan, alapvetöen termékalapon (értéklánc mentén) szerveződött, a különbözỏ gazdasági szereplöket, intézeteket és nonprofit szervezeteket magában foglaló, területileg koncentrált kooperációs hálózatot értủnk klaszter alatt, amely jelentős mértékben hozzájárul nemcsak az abban résztvevôk, hanem az egész régió versenyképességének növekedéséhez ${ }^{2}$.

A koncepció meghaladja az egyszerü horizontảlis kapcsolatok hálózatát, amely az egyazon piacon és iparágban érdekelt vállalkozások különbözó típusú együttmúködésében realizálódik (közös $\mathrm{K}+\mathrm{F}$, marketing, értékesítési politika). Sokkal inkább egy ágazatok közötti hálózat, amely az értékláncnak egy speciális kapcsolata vagy tudảsbázisa mentén elhelyezkedő, de egymástól különböző, vagy egymást kiegészítô vállalkozásokat foglal magában.

\section{A klaszterek legfontosabb jellemzöi}

A definícióból következően Steiner szerint a klasztereknek három alapvető, közös tulajdonsága figyelhető meg (Steiner 1998).

Az első a kifinomult munkamegosztáson alapuló erőteljes specializáció, amely a szoros beszállítói kapcsolatokon alapul. Ezek a kapcsolatok természetesen rendkívül változatosak lehetnek. A legegyszerübb input-output beszállítói (a termékek mellett persze ideértve a legkülönbözöbb szolgáltatásokat is) kapcsolatoktól kiindulva egészen a kutatóintézetek és a gazdasági szervezetek között megvalósuló tudásátadásig, vagy a vállalkozások és a gazdaságfejlesztéssel foglalkozó különböző szervezetek (ügynökségek, alapítványok) közötti együttmúködésekig terjedhetnek.

A szereplök közötti szoros kapcsolatok kialakulásának az egyik legfontosabb elófeltétele és a klaszterek második közös tulajdonsága a földrajzi közelség megléte. Az erőteljes földrajzi koncentráció adja meg a klaszterek regionális dimenzióját, amely nélkülözhetetlen a részt vevő gazdasági szervezetek versenyképessége szempontjából, fontos olyan folyamatok rugalmas müködtetéséhez, mint a ,just-in-time”, az outsourcing, vagy a hatékony tudásátadás.

Végül a vállalkozások és az egyéb szervezetek koncentrált elhelyezkedése (földrajzi közelsége), illetve az egymással való szoros együttmúködés spillover és szinergiahatásokhoz vezet. A gyors tudás és információáramlás és az extern hatások nemcsak a klaszterben résztvevők számára járnak igen jelentős gazdasági elönyökkel, hanem a termelékenységnövekedés, növekedés, gazdasági stabilitás és foglalkoztatás révén az egész térség versenyképességét javítja.

A klaszter tehát jelentős versenyelönyökhöz juttatja a benne részt vevő vállalkozásokat anélkül, hogy azok elveszítenék rugalmasságukat, amelyeket általában csak a nagyobb méretü cégek képesek elérni. Az elönyöket a vállalatok versenyképességének növelésével, az innováció terjedésének élénkítésével és az új ủzleti kapcsolatok kialakulásának elősegítésével erősíti (Porter 1999). 


\section{A klaszterek szereplöi}

Az ipari klaszterek meghatározó szereplöi az értéklánc végén elhelyezkedő, az iparág elsődleges javait előállító olyan multinacionális nagyvállalatok, amelyek a nemzetközi porondon is versenyképesnek bizonyulnak. Ezekhez a nagyvállalatokhoz ezer szállal kapcsolódnak a beszállító cégek. Ezek a főleg kis- és közepes méretü vállalkozások a legkülönfélébb inputokkal látják el az elóző kategóriához tartozó cégeket (a nyersanyagok, alapanyagok és alkatrészek mellett természetesen ide értendök a gépek, berendezések, sőt a szolgáltatások illetve az infrastruktúra is). A gyártók és a fogyasztók közötti kapcsolatot és az elkészuilt javak piacra juttatását hivatottak biztosítani az értékesitésében részt vevö vállalkozások, hálózatok (lefelé való terjeszkedés). Ugyanakkor az iparág elsődleges javaihoz kiegészitő termékeket gyártó, vagy kiegészitö szolgáltatásokat nyújtó cégek, illetve a más iparágakban müködö, de a közös szakértelem, technológia és inputok révén kapcsolódó vállalkozások is hozzájárulnak a klaszter versenyképességének alakulásához (oldalirányú terjeszkedés).

A régió gazdasági aktorai mellett az állami és magánszférához tartozó különbözö típusú intézetek alkotják a klaszter másik fontos pillérét. A felsőoktatási intézetek (elsősorban az egyetemek) szorosan együttmüködve a vállalkozásokkal, aktívan részt vesznek az iparág legkülönbözöbb speciális oktatással, képzéssel és információnyújtással kapcsolatos igényeinek kielégítésében. A kutatóintézetek pedig $\mathrm{K}+\mathrm{F}$ tevékenységükkel és a megfelelö technológiai infrastruktúra biztosításával támogatják a vállalkozások sikerességét (Döry 1999; Porter 1999; Steiner 1998). A Porteri megfogalmazás szerint egyszerre foglal magában egymással versenyző és együttmüködö vállalkozásokat ${ }^{3}$. A klaszter legkülönbözöbb szereplőit és a köztük lévő kapcsolatokat szemlélteti a 2. ábra a Walesi gépjármüipari klaszter példáján.

\section{2. ÁBRA}

A Walesi gépjármüipari klaszter

(Automotive Cluster in Wales)

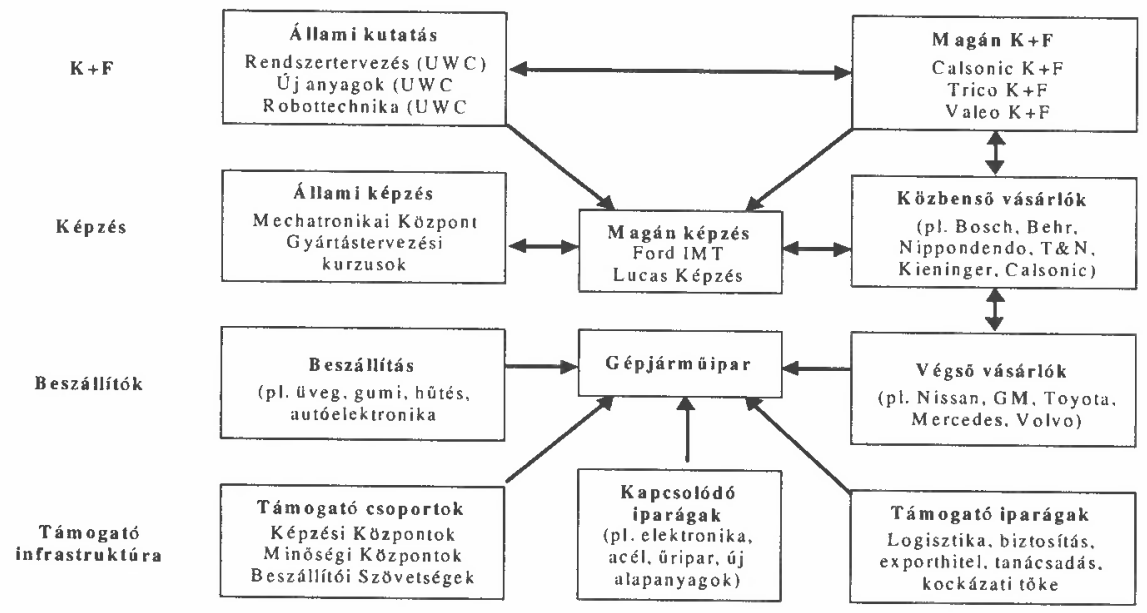

Forrás: Cooke 1998. 


\section{Klaszter típusok}

A klasztereknek különböző típusai különböztethetők meg (Rechnitzer 1998; Steiner 1998).

- A tudáshoz kapcsolódó infrastruktúrához erős szálakkal kötődő gazdasági tevékenységek földrajzi koncentrációja (más néven tudás-klaszter) elsősorban a nagy egyetemi városok és a kutatóintézetek köré letelepülő vállalkozásokkal érhetô tetten.

- A sokkal szúkebb értelemben vett iparágak, ágazatok vertikális termelési kapcsolatai és beszállitói láncai. A tradicionális kézmüipari együttmüködések legjobb példája az észak-olasz kis- és középvállalkozások szoros együttmüködése (föleg a textil- és ruházati iparban, a cipö- és böriparban, fafeldolgozó- és bútoriparban).

- A különbözö aggregációs szintek mentén történő ágazati koncentráció föleg az autóipar vagy az elektronikai ipar területén müködő, illetve ezen iparágakhoz valamilyen mértékben kapcsolódó vállalkozások körében. Jó példa erre a felsőausztriai autóklaszter, vagy a walesi gépjármüipari illetve elektronikai ipari klaszter (3. ábra).

\section{3. ÁBRA}

Autóipari klaszterek Európában (Automotive Clusters in Europe)

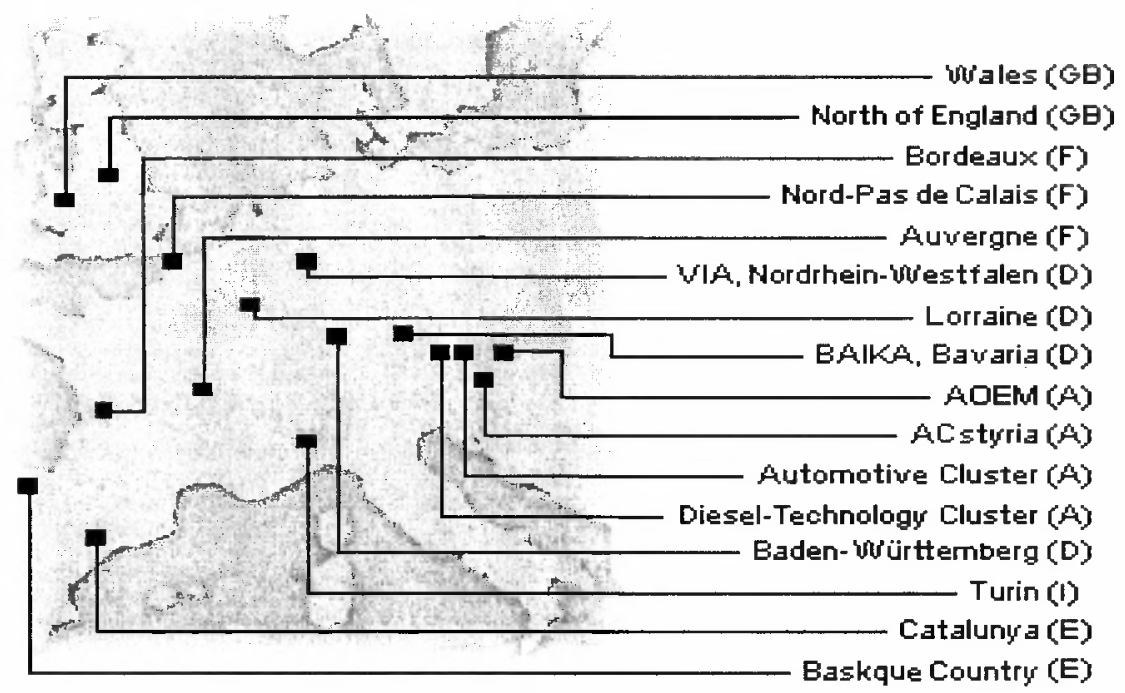

Forrás: www.automobil-cluster.at.

- A közös alaptechnológiát kifejlesztő és azt alkalmazó vállalkozások és intézmények közötti szoros kapcsolat. San Francisco környékén a biotechnológia, Los Angeles környékén pedig az ürtechnológia tölt be ilyen klaszterképző funkciót, azonban hasonló folyamatok figyelhetők meg a géntechnológia vagy a mủszergyártás területén is. 
- A közös kereslet vagy közös szükséglet kielégítése érdekében szervezödő vállalkozások csoportosulása (öko-klaszter).

- A tercier szektorra épülö klaszterek általában a nagyvárosok központjában koncentrálódnak, mint pl. a pénzügyi szolgáltatások New Yorkban, vagy a divat-• világ Párizsban.

\section{Klaszter-épités}

A klaszter-épités folyamatára egyaránt jellemző a felülről lefelé és az alulról felfelé való irányultság (Molina 1998). Maga a klaszter-építés alapvetően egy bottom-up típusú törekvés megvalósítása, amely az adott helynek, térségnek, régiónak a már meglévő kulturális és ipari hagyományaira és erősségeire építve, megpróbálja azokat minél hatékonyabban hasznosítani. A klaszter-építés folyamatában azonban határozott top-down szerepet kapnak azok a szervezetek illetve intézmények, amelyek jelentős szerepet játszanak a gazdaságfejlesztés vagy a vállalkozásfejlesztés területén. Ezen szervezetek elsődleges feladata a klaszter folyamat felülről történő élénkítése és katalizálása. Végül a siker érdekében elengedhetetlen, hogy az alulról felfelé, illetve a felülről lefelé irányuló folyamatok legyenek nagyon pontosan összehangolva egymással, hiszen csak így biztosítható a kívánt szinergia hatások elérése.

$\mathrm{Az}$ OECD létrehozott egy ipari klaszterekkel foglalkozó ún. Fókusz Csoportot, amely 1997-1998-ban összesen 15 OECD tagállamában folytatott vizsgálatot, összehasonlítva az egyes országok klaszter-politikájának és azok megvalósításának sajátosságait a meglévő hasonlóságok után kutatva. E vizsgálatok alapján Roelandt és den Hertog fogalmazta meg a klaszter-alapú politika legfontosabb alapelveit, melyek a következök (Roelandt-den Hertog 1998):

- A klaszter-épités folyamatának elsősorban a piac által elöidézettnek, és a piac által vezérelt kezdeményezésnek kell lennie. A gazdasági szereplők kifejezésre juttatott érdekeltsége, azaz az eröteljes piaci igény hiányában a puszta kormányzati szándék nem vezet célhoz. A klaszterizációt nem lehet erőltetni.

- A központi kormányzati politikában nem szabad, hogy egyes iparágak, vállalat(csoportok) érdekében hangsúlyos szerepet kapjon a piaci verseny korlátozása. A közvetlen ipartámogatást és vállalkozástámogatást, valamint a közvetlen piaci beavatkozást fel kell váltani a közvetett segítségnyújtásnak.

- A kormányzatnak a klaszter kezdeményezésben nem közvetlen irányítói vagy tulajdonosi szerepet kell betöltenie, e funkciókat a piaci szereplők jóval eredményesebben és hatékonyabban képesek ellátni. A központi kormányzatnak sokkal inkább egyfajta katalizátorként kell elősegitenie a legkülönbözöbb szereplök egymásra találását és az újabb együttműködések kialakulását. Emellett részt vesz a beszállítói rendszerek támogatásában és a klaszterizációs és innovációs folyamatok ösztönzésében. 
- A klaszter-politikának nem szabad csak a már meglévő és sikeresen müködő klaszterekre helyezni a hangsúlyt. Figyelemmel kell kísérnie, és támogatnia, ösztönöznie kell a kisebb, illetve a még kialakulófélben lévőket is.

A klaszter-orientált iparpolitika alapját, mint azt a piramis is mutatja az eszközök és az intézmények mellett a tudatosság kialakítása alkotja (4. ábra). Rendkívül fontos, hogy a klaszter filozófiát a vállalkozások és a regionális intézményrendszer valamennyi tagja megismerje és magáévá tegye, hiszen mint azt fentebb említettük, a piaci szereplök erőfeszitésén múlik annak sikere.

\section{4. ÁBRA}

A klaszter-orientált iparpolitika

(Cluster-orientated Industrial Policy)

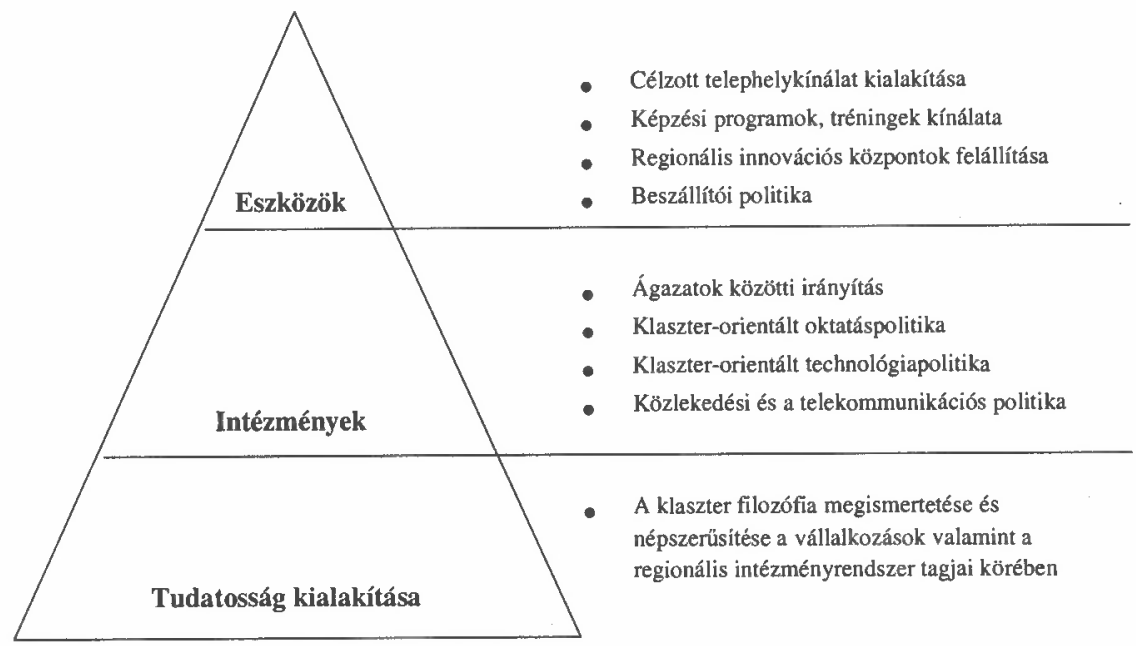

Forrás: Clement 1998.

\section{Lehetséges klaszterek Magyarországon}

A rendszerváltást követö elmúlt évtizedben radikálisan átalakult a magyar gazdasági szerkezet. Elsősorban a külföldi müködőtőke beruházásoknak köszönhetően egy duális gazdasági struktúra jött létre, aminek köszönhetỏen a - föleg a gépipar területén müködő, általában vámszabad területeken vagy vállalkozási övezetekben megtelepedett - külföldi multinacionális vállalatoknál keletkezik a bruttó hazai termék és az export meghatározó hányada. Ez a mintegy félszáz cég azonban egyelöre képtelen volt beágyazódni a magyar gazdaságba, szigetszerü müködésük során megtartották jól bevált, szintén külföldi beszállitóikat és egyelöre csak elvétve tapasztalható a hazai kis- és középvállalkozásokkal való együttmüködés, vagy komolyabb üzleti kapcsolat kialakítása. A magyar kis- és középvállalkozások elsösorban a külföldi nagyvállalatok igen magas minöségi és technológiai követelményeinek köszönhetöen - képtelenek voltak kapcsolódási pontot találni, és kivenni a foglalkoztatottságban betöltött szerepüknek megfelelö részesedést a multik által 
gerjesztett általános növekedésböl. Különösen igaz ez a kutatás-fejlesztési tevékenységre, illetve általában az innovációk területére.

Ennek oldása érdekében Magyarországon vélhetően erős kormányzati támogatásban fog részesülni a klaszterek kialakítása, mely szorosan összefügg a duális gazdaságszerkezet oldását szolgáló beszállító programmal. A Széchenyi-tervben különös hangsúlyt kap a vállalkozói kapcsolatok és ismeretek bỏvülését szolgáló információs, képzési és nemzetközi kapcsolatépítési programok támogatása, a vállalkozói hálózatok fejlesztése, valamint a különböző termék-klaszterek kialakítása, amelyek egyúttal elösegitik a beszállítói szerepre törekvő kis- és középvállalkozások multinacionális cégekkel való üzleti kapcsolatainak kialakítását is.

$\mathrm{E}$ folyamatok tükrében Magyarországon is lépések történtek iparági klaszterek kialakítására ${ }^{4}$, melyek legfontosabb célja a már megtelepedett multinacionális nagyvállalatok és a hazai kis- és középvállalkozói szektor közötti együttmüködés elősegítése. A hazai kis- és középvállalkozásoknak a multikhoz való sikeres integrálódásból származó elönyök mellett kérdéses, hogy a külföldi cégeknek milyen előnyük származik abból, ha fokozatosan hazai, elsősorban a közvetlen földrajzi környezetükben múködő vállalkozásokra cserélik eddigi, jól bevált beszállitói kapcsolataikat. Természetesen a puszta földrajzi közelségből, és így a szállitási költségek csökkenéséböl eredö költségelönyök is rendkívül fontosak a nemzetközi piacon megmérettetett vállalatok számára, azonban legalább ilyen jelentỏséggel bír, hogy közvetlen környezetükben a szoros együttmüködésekkel lehetőségük van a kis- és középvállalkozásokat saját képükre formálni, és egy olyan innovációs miliốt létrehozni, amely a hatékony és gyors információáramlás és interakciók révén jelentős mértékben hozzájárulhat versenyképességük növekedéséhez.

Nagyon fontos megjegyezni, hogy a kormányzatnak a nemzetközi tapasztalatok alapján csak olyan ipari klaszterek kialakulását szabad elősegítenie, amelyet az abban részt vevő vállalkozások is erősen támogatnak, hiszen nem szabad elfelejteni, hogy a klasztereknek középtávon önfenntartókká kell válniuk, ami jelentős piaci igény megléte és az érdekeltek elkötelezettsége nélkül vágyálommá válhat. Tehát a klaszter-szervezésben a legfontosabb feladatok elvégzését alapvetően a piaci szereplők kezében kell hagyni, a kormányzat részvétele - a pénzügyi háttér kezdeti megteremtését követően - sokkal inkább támogató, katalizátor jellegü kell, hogy legyen.

A klaszterek határait és így a kooperáció területi dimenzióját mindenképpen az abban részt vevő vállalkozások és intézmények közötti együttmüködések határozzák meg, így ebből kifolyólag nem kötelezően esnek egybe a meglévő politikaiközigazgatási határokkal, egyes esetekben még az államhatárokkal sem Magyarországon a klaszterek létrehozása minden bizonnyal szorosan kapcsolódik majd a tervezési-statisztikai régiókban felállításra került regionális fejlesztési tanácsok által kezdeményezett regionális programokhoz. Így félő, hogy a létrehozandó klaszterek a régiók elsődleges törekvéseinek megfelelve elsősorban az ezen határokon belül elhelyezkedö vállalkozások és intézmények együttmüködésére helyezik a hangsúlyt. A klasztereket és az együttmüködéseket azonban nem szabad 
a tervezési-statisztikai régiók keretei közé szorítani. Mindenképpen nyitottnak kell maradniuk a szomszédos térségek - sőt szomszédos országok - vállalkozásai és intézményei felé is.

\section{Jegyzetek}

${ }^{1}$ A tanulmány során a nemzetközi szakirodalomnak megfeleb̈en a klaszterek kifejezést használjuk, melynek jelentése fürt, csoport, csoportosulás, annak ellenére, hogy azt a hazai nűvekben többféleképpen is megpróbálták lefordítani (iparági csoportosulások, regionális üzletági központok stb.).

${ }^{2}$ A klaszterekben rejlő elönyökre utal az egyik gyakran használt angol megnevezés is: Flock of Birds, azaz madárraj, amely arra utal, hogy együtt, egymással együttmüködve sokkal könnyebb elérni a kívánt célt, mint külön-külön.

${ }^{3}$ Ennek megfelelöen az angol co-operative és a competitive szavakból képezhebỏ a co-ompetitive kifejezés, amely kifejezi mind a verseny, mind az együttmüködés lehetöségét.

${ }^{4}$ A legelórehaladottabb stádiumban a Nyugat-Dunántúlon szervezödö autóipari klaszter van, amely élvezi a legjelentösebb multinacionális vállalatok támogatását is (AUDI, GM-Opel, WAV stb.).

${ }^{5}$ Példaként említhetők az Egyesült Államokban a szövetségi államok határain átnyúló különbözỏ kooperációk, vagy a német svájci határon átnyúló vegyipari koncentráció.

\section{Irodalom}

Clement, W. (1998) Clusters: New Developments in Austria and their Relevance in Economic Policy. Clusters and Regional Specialisation on Geography Technology Networks. - Steiner, M. (ed.), London, European Research in Regional Science. 8. 254-268. o.

Cooke, P (1998) Global clustering and regional innovation: systematic integration in Wales. Regional Innovation Systems. The Role of Governances in a Globalised World. - Braczyk, H-J.-Cooke, P.-Heidenreich, M. (eds.), London-Pennsylvania, UCL Press. 245-262. o.

Dőry T. (1998) Beszállítói kapcsolatok és az ipari együttmüködés lehetséges klaszterei a KözépDunántúlon. - Tér és Társadalom. 3. 88-92. o.

Döry T. (1999) A linzi „automobil-klaszter”, autóipari hálózat felépítése Felsö-Ausztriában. - Kisalfóldi Gazdaság. december 17. 14. o.

Dusek T. (1999) A teruletfejlesztés megújítási iránya, az ipari körzetek - Tér és Társadalom. 1-2. 89108. o.

Faragó L. (1994) Regionális gazdaságfejlesztés „kereslet-oldali” stratégiák segítségével. - Comitatus. december. 60-63. 0 .

Lengyel I. (1999) Régiók versenyképessége (A térségek gazdaságfejlesztésének fobbb közgazdasági fogalmai, alapgondolatai, tényezói az EU-ban). Szeged, JATE Regionális és alkalmazott Gazdaságtani Tanszék. Kézirat.

Marshall, A. (1890) Principles of Economics. London, Macmillan.

Molina, A. (1998) Industrial Clusters and Knowledge Sharing Constituencies. Aggregated analysis of UK workshop. 17-18 June. Edinburgh.

Porter, M. E. (1990) The Competitive Advantage of Nations. New York, The Free Press.

Porter, M. E. (1999) Regionális üzletági központok - a verseny új közgazdaságtana. - Harvard Business Manager. 4. 6-19. o.

Rechnitzer J. (1998) Terïleti stratégiák. Budapest-Pécs, Dialóg Campus.

Roelandt, T.-P. den Hertog (1998) Summary Report of the Focus Group on Clusters. OECD.

Széchenyi-terv. Nemzeti Fejlesztési Terv. (2000) Budapest, Gazdasági Minisztérium. (tervezet)

Steiner, M. (1998) The Discrete Charm of Clusters: An Introduction. Clusters and Regional Specialisation on Geography Technology Networks. - Steiner, M. (ed.), London, European Research in Regional Science 8. 1-17. o.

Zeitlin, J. (1994) Ipari körzetek, regionális gazdasági megújulás. - Közgazdasági Szemle. 1. 14-25. 


\title{
INDUSTRIAL CLUSTERS
}

\begin{abstract}
ANDRÁS GROSZ
Industrial clusters are geographically concentrated networks of production of strongly interdependent firms linked to each other in a value-adding production chain. Besides the major manufacturers and the connecting suppliers, universities, research institutes, knowledge intensive business services and transfer institutions are also included in the clusters. Clusters increase the competitiveness of not only the individual participant but also the whole region. Consequently the building of industrial clusters (e.g. automotive, electronic, etc.) emerged to the centre of both economic and regional development in the whole world. There are also some initiatives for cluster development in Hungary and the government responds to it quite positively. Therefore it can be useful to shortly examine the theoretical background and the international experiences of clusters and cluster policies for the better application and implementation in Hungary.
\end{abstract}

